\begin{tabular}{|l|l|l||}
\hline \multicolumn{2}{|c|}{ PublisherInfo } \\
\hline \hline PublisherName & $:$ & BioMed Central \\
\hline \hline PublisherLocation & $:$ & London \\
\hline \hline PublisherImprintName & $:$ & BioMed Central \\
\hline \hline
\end{tabular}

\title{
VEGF and bone resorption by osteoclasts
}

\begin{tabular}{|l|l|l||}
\hline \multicolumn{2}{|c||}{ ArticleInfo } \\
\hline \hline ArticleID & $:$ & 3 \\
\hline \hline ArticleDOI & $:$ & $10.1186 /$ ar-1999-66723 \\
\hline \hline ArticleCitationID & $:$ & 66723 \\
\hline \hline ArticleSequenceNumber & $:$ & 3 \\
\hline \hline ArticleCategory & $:$ & Paper Report \\
\hline \hline ArticleFirstPage & $:$ & 1 \\
\hline \hline ArticleLastPage & $:$ & 3 \\
\hline \hline & & RegistrationDate : 1999-8-20 \\
\hline ArticleHistory & $:$ & OnlineDate \\
\hline ArticleCopyright & $:$ & Current Science Ltd1999-8-20 \\
\hline \hline ArticleGrants & $:$ & \\
\hline \hline ArticleContext & $:$ & 1307511 \\
\hline \hline
\end{tabular}




\section{Keywords}

Bone resorption, osteoclasts, macrophage colony-stimulating factor, VEGF

\section{Context}

Osteopetrotic (op/op) mice have a deficiency for osteoclasts that is caused by a mutation in the gene for macrophage colony-stimulating factor (M-CSF). A single injection of M-CSF is sufficient to induce osteoclast recruitment and survival in op/op mice. The action of M-CSF is mediated by the receptor cFms, a member of the platelet-derived growth factor (PDGF) receptor family. Vascular endothelial growth factor (VEGF), a potent stimulator of blood vessel formation, also acts through members of the PDGF receptor family, including Flt-1, Flk-1 and neuropilin. In contrast to endothelial cells, which express all of the VEGF receptor subtypes, cells of the monocyte/macrophage lineage express the Flt-1 receptor only. Because of the close lineage relationship between macrophages and osteoclasts, VEGF could compensate for the deficiency of M-CSF in op/op mice in terms of osteoclastic bone resorption. To investigate whether VEGF can substitute for M-CSF in stimulating osteoclast recruitment in op/op mice.

\section{Significant findings}

A single injection of either M-CSF or VEGF was sufficient to induce osteoclast recruitment in op/op mice. Osteoclasts were strongly stained with anti-Flt-1 antibody only, whereas endothelial cells were positive for both Flt-1 and Flk-1 receptors. Neutralisation of endogenously produced VEGF in op/op mice with injections of Flt-1/Fc chimeric protein decreased the number of M-CSF-recruited osteoclasts to $\sim 25 \%$. In contrast, when M-CSF was injected together with Flt-1/Fc chimeric protein, osteoclast number increased to the levels observed in mice consecutively injected with M-CSF alone. Resorption of bone trabeculae and replacement with bone marrow in femurs were observed in the femurs of op/op mice that had received either a single M-CSF injection only or consecutive injections of Flt-1/Fc and MCSF in addition to the single M-CSF injection. A combination of VEGF and ODF supported the generation of TRAP-positive cells, and formed resorption lacunae, although lacunae were smaller than those supported by a combination of M-CSF and ODF. Progressive correction of osteopetrosis with age was accompanied by an increase in osteoclast numbers in op/op mice, due to endogenously produced VEGF. Injections of anti-VEGF polyclonal antibody significantly decreased osteoclast numbers. 


\section{Comments}

VEGF is considered to play a central role in maintaining the invasive pannus in rheumatoid arthritis (RA), due to its activity in stimulating new blood vessel formation. As a consequence, inhibition of VEGF activity has been proposed as an adjunct to conventional anti-RA therapy, to decrease the supply of nutrients and oxygen to the pannus and hence reduce synovial mass. The study by Niida et al. demonstrates that VEGF may also be important in recruitment of osteoclasts. Loss of bone mass is commonly associated with RA and this is now considered to be due to the increased activity of osteoclasts, which have been observed to resorb bone at the site where the proliferating synovial membrane invades the adjacent bone in RA. The data reported in this paper suggest that blockade of VEGF activity in RA, in addition to downregulating angiogenesis and vascular permeability, might also reduce osteoclastic bone resorption. Since osteopenia is responsible for co-morbidity (such as increased femoral fracture risk) in RA patients, this would be an additional and hitherto unexpected benefit of antiVEGF therapy.

\section{Methods}

Mice of the op/op genotype were injected with recombinant cytokines (VEGF, M-CSF), then killed; the femurs removed and decalcified. Longitudinal sections of whole femurs were stained for tartrateresistant acid phosphatase (TRAP) activity and counter-stained with hematoxylin. TRAP-positive cells with two or more nuclei were counted as osteoclasts. To measure VEGF receptor expression, femurs of op/op mice were fixed, paraffin-embedded and stained with anti-Flt-1 or anti-Flk-1 antibodies. In another series of experiments, op/op mice were pretreated with a single injection of M-CSF, followed four days later by injection of Flt-1/Fc chimeric protein and/or M-CSF. Finally, osteoclasts were generated in vitro from bone marrow cells by culturing them with osteoclast differentiation factor (ODF) in the absence or presence of VEGF or M-CSF.

\section{References}

1. Niida S, Kaku M, Kaku M : Vascular endothelial growth factor can substitute for macrophage colony-stimulating factor in the support of osteoclastic bone resorption. J Exp Med. 1999, 190: $293-293$.

This PDF file was created after publication. 